\title{
DEVELOPMENT OF A FODDER BEET CHOPPING MACHINE
}

\author{
M. M. IBRAHIM *
}

\section{ABSTRACT}

The objective of the present investigation was to modify some parts of the local watermelon seeds extraction machine, where the developed machine can be used with the extraction of watermelon seeds and chop the fodder beet. The developed machine has been evaluated under three beet moisture contents of 86.2, 81.3 and $76.85 \%$, four rotor speeds of 325, 405,460 and $540 \mathrm{rpm}$ and three number of knives rows of 2, 3 and 4 rows. The evaluation was based on the following parameters: The chopping sizes, machine productivity, consumed energy, and chopping cost.

The results recommended operating the machine at rotor speed of 540 rpm, number of knives rows of 4 row and beet moisture contents of 86.2 $\%$ to maximum values of beet sizes $<2 \mathrm{~cm}(71 \%)$ and maximum machine productivity $\left(10.25\right.$ ton $\left.^{-1}\right)$, with consumed energy of $1.08 \mathrm{~kW} . \mathrm{h} \mathrm{ton}{ }^{-1}$ and the minimum chopping cost of 20.49 L.E ton ${ }^{-1}$.

Keywords: fodder beet, design, chopping, consumed energy.

\section{INTRODUCTION}

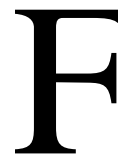
lodder beet (Beta Vulgaris L.) is considered a good source of energy for animal feeding, palatability and digestibility. Fodder beet cultivation may overcome the problem of animal feeding at the beginning of summer season but it still has a weak competitive ability against be clover seem as winter forage.

Fodder beet contains high water and sugar, it increases milk productivity and is suitable forage for dairy cows. The fodder beet is used by mixing it with straw in European countries. It is also reported that the plant is suitable for making silage (Aky ld $z$ 1983).

In Egypt, the great shortage in animal feed stuffs and their distribution around the year are the main problems facing animal production. There is a shortage of fresh forage particularly during summer. Moreover, the cultivated area is very limited and is devoted to cultivation of strategic food crops such as wheat and faba beans during winter.

\footnotetext{
"Assoc. Prof., Ag. Eng. Dept., Fac. of Agric., Cairo University.
} 
On the other hand, the horizontal expansion of new reclaimed areas requires the cultivation of crops offering a source for satisfying income to the farmers (Kassab et al., 2012).

In Egypt, the fodder beet is grown each year, cultivated area is about 9674 ha and quantity of production was 244626 tons (FAOSTAT, 2010).

Increasing and expanding fodder beet can be realized by finding new and additional areas without changing the prevailing winter crop structure through intercropping with some winter crops (Abou-Elela and Gadallah, 2012).

Fodder beet offers a higher yield potential than any other arable fodder crop and when grown under suitable conditions, it can produce almost 20 $\mathrm{t} \mathrm{ha}^{-1}$ dry matter yield $(\boldsymbol{D A F}, \mathbf{1 9 9 8})$ and also fresh yield more than $80 \mathrm{t} \mathrm{ha}^{-1}$. (Shalaby et al., 1989). The above and below growth parts (leaves and roots) are used to feed the animals but, the main fodder is tuberous roots (Ibrahim, 2005). Therefore, the optimum plant density which produces maximum leaves and roots yield must be carefully determined. Fodder beet is good forage especially during the critical period of forage shortage such as early summer season in Egypt.

Chopping fodder beet roots are the main point for feeding small ruminants in this connection, Gabra et al. (1993) reported that biting roots by sheep was slow, hard and negatively affected daily intake. They concluded that chopping roots at small pieces are suitable for the pointed mouth of sheep and may increase feed intake and feeding values.

Hashish et al. (1994) indicated that the theoretical cut of $13 \mathrm{~mm}$ is usually considered fine enough for corn silage, longer cut $(50-75 \mathrm{~mm})$ are desirable for cured hay. With any crop, chopping into lengths shorter than necessary increase the energy requirements per megagram and may reduce the capacity of the chopper. Kholief (2001) pointed out that the increase of drum speed from 14.52 to $22.31 \mathrm{~m} \mathrm{~s}^{-1}$ leads to increase the unit energy consumption of chopped fodder beet by 16.36, 12.74, 11.05 and $10.97 \%$ at feed rates of 100.2, 130.2, 169.8 and $199.8 \mathrm{~kg} \mathrm{~h}^{-1}$ respectively by using fodder beet moisture content of $72.34 \%$ (w.b.). 
Mohamed (1998) mentioned that the maximum force needed to cut the beet in the upper part was $540 \mathrm{~N}$, the middle part $430 \mathrm{~N}$ and the root part was $188 \mathrm{~N}$.

The objective of the present investigation was to modify some parts of the local extraction machine of watermelon seeds, where the developed machine can be used with the extraction of watermelon seeds and chop the fodder beer.

\section{MATERIALS AND METHODS}

The experimental work was carried out during summer season 2015 at Kafer El-Sheikh Governorate - Egypt. The developed mechanism was fabricated in private workshop. The fodder beet (Rota variety - Multi embryos) was randomly collected from different farms from Kafr ElSheikh Governorate. The specimens gathered from the field were weighed and dried at $103^{\circ} \mathrm{C}$ for $24 \mathrm{~h}(\boldsymbol{A S A E}, 1999 \boldsymbol{a})$. The moisture content of fodder beet was $86.2 \%$ w.b.

\section{The original machine}

The original machine Fig. (1) performs its function in three processes. The first process for crushing watermelon fruits, while the second process for separating peel from the mixture of seed and flesh and the last process for cleaning the seeds from flesh. The machine consists of main hopper which contains two main shafts. The upper one drives the cutting knifes and the lower drives crushing shaft. The Machine was driven by a transmission system connected to the PTO of tractor ( $60 \mathrm{hp})$ by means of a pair of sprockets and chains, and a universal joint.

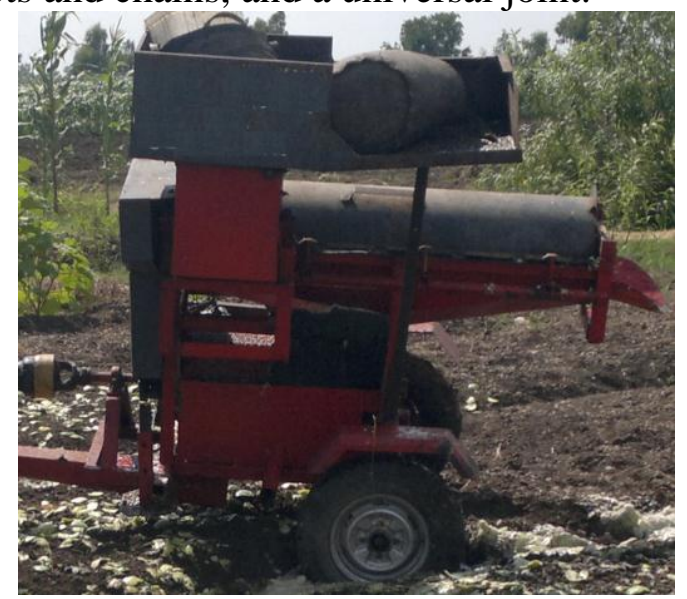

Fig. (1): The original machine 


\section{Design consideration}

The some parameters were considered in the design of the some parts of the developed machine: easy of operation, reduction of the energy requirements, economy to make the machine affordable and within the capacity of the local farmers, using standard component and local available material.

Some physical and mechanical properties of fodder beet were studied that are related to cutting process.

\subsection{Physical properties}

Three axial dimensions (length, width, and thickness), mass and volume were measured according to Mohsenin (1986).

\subsection{Coefficient of static friction}

The static coefficient of friction of fodder beet against galvanized metal was determined at moisture content of $86.2 \%$ w.b. A device was used for the determination of the coefficient of friction as shown in figure (2) according to Ibrahim (2008). The static coefficient of friction was calculated as follows:

$$
\mu=\frac{F_{T}-F_{E}}{W}
$$

Where

$\mu \quad$ : Coefficient of static friction.

$\mathrm{F}_{\mathrm{T}} \quad$ : Force required to start motion of filled carriage, $\mathrm{N}$.

$\mathrm{F}_{\mathrm{E}}$ : Force required to start motion of empty carriage, N.

W : Vertical weight, N.

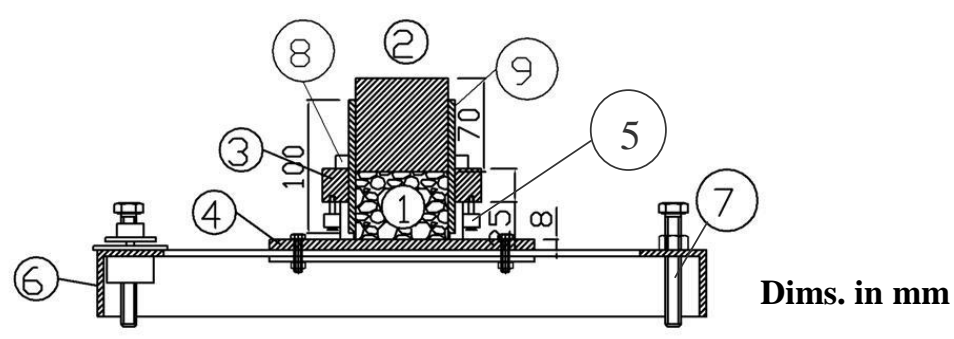

1-Sample

2- Piston (vertical loads)

3- Carriage

4- Sliding surface

5- Rolling wheels

6- Base

7- Adjustable screw

8- Adjustable nut

9- Cylinder

Fig. (2): The device used for measuring the friction force. 


\subsection{Shearing stress}

The ultimate shear strength test was carried according to $(A S A E, 1999 b)$. Cylindrical samples of fodder beet with a diameter of $25 \mathrm{~mm}$ were cut from the centre fodder beet using a cork borer and then trimmed to a height of $25 \mathrm{~mm}$. The core samples were taken perpendicular to the major axis of the tubers.

The shear force was measured in double shear using a shear box (Fig. 3) consisting essentially of to fixed parallel hardened steel plates $15 \mathrm{~mm}$ apart, between which a third plate can slide freely in a close sliding fit. Shear force was applied to the cylinder specimens by mounting the shear box. The test was carried out between the standard Instron stainless steel polished platens of a model Instron Universal Testing Machine (Instron, USA) using a $1 \mathrm{kN}$ load cell.

The shear stress was calculated as follows:

$$
\tau=\frac{F}{2 A}
$$

Where

$$
\begin{array}{rll}
\tau & : & \text { Shear stress, } \mathrm{MP}_{\mathrm{a} .} \\
\mathrm{F} & : & \text { Shear force at failure, N. }
\end{array}
$$

A : Initial cross - sectional area, $\mathrm{mm}^{2}$.

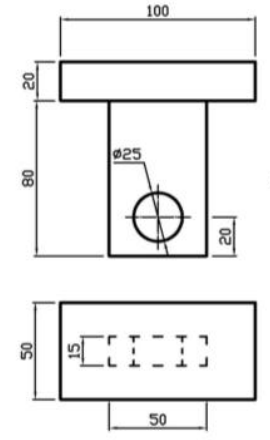

Loading plate
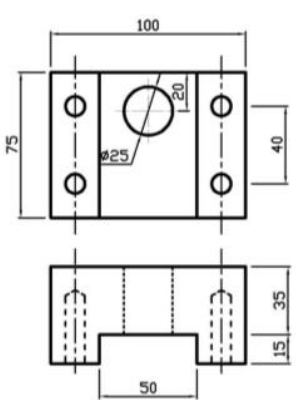

Supported plates
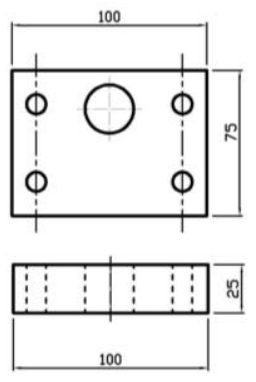

Dims. in mm

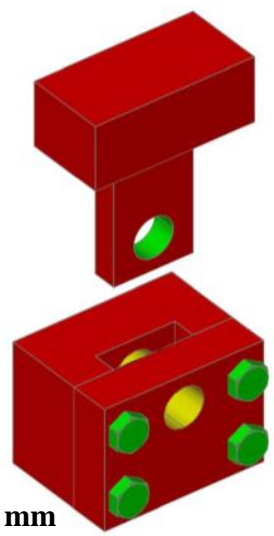

Fig. (3): The shear force measuring device.

The shearing energy was calculated by integrating the area under the shear force and displacement curve (Chen et al., 2004). The specific shearing energy was calculated from the following: 


$$
E_{S C}=\frac{E_{S}}{A}
$$

Where

Esc : Specific shearing energy, $\mathrm{mJ} \mathrm{mm}^{-2}$.

Es : Shearing energy, $\mathrm{mJ}$.

A : Initial cross - sectional area, $\mathrm{mm}^{2}$.

\section{The developed machine}

The developed parts of the original machine are cutting knives, cutting chamber, and the driving unit (Fig. 4).

\subsection{Feeding unit}

The major parameter governing the size and configuration of the feed hopper is the throughput capacity of the machine. The hopper must be able to accommodate enough fodder beets to achieve the required throughput capacity. It is cuboids shape and it was made of $2 \mathrm{~mm}$ thick plate. It was dimensioned $1200 \times 750 \times 300 \mathrm{~mm}$ and the opening rectangle hole in the base $500 \times 500 \mathrm{~mm}$, to deliver the beet to the cutting unit.

\subsection{Cutting unit}

The cutting unit works on shear cutting principle. When the cutting blade impacts on the cylindrical surface of the fodder beet, the surface gets cut by shearing along a plane. Spiral cutter was also reported to be used for chopping (Persson, 1987). The length and diameter of this cylindrical cutter were $500 \mathrm{~mm}$ and $150 \mathrm{~mm}$ respectively so that it could be fitted in the available machine.

The blades were made of MS plat of size 64 x $55 \mathrm{~mm}$ and $10 \mathrm{~mm}$ thickness. The cutting edge sharpened at the angle of $90^{\circ}$. The 2 or 3 or 4 rows of knives (each row consist of 16 knives). The knives were welded directly on the cylindrical cutter shaft and they were fixed as spiral arrangement (Fig. 5).

Determination of the shearing force of the fodder beet: Considering the shear strength of the fodder beet and the area under shear, the impact force required to shear the fodder beet by one knife may be obtained from the following equation:

Where

$$
\mathrm{F}_{\mathrm{P}}=\mathrm{A}_{\mathrm{P}} \times \tau_{\mathrm{P}}
$$

$\mathrm{F}_{\mathrm{P}} \quad$ : Force required for shearing the fodder beet, $\mathrm{N}$. 
$A_{P} \quad: \quad$ Area under shear (area of one knife).

$\tau_{\mathrm{P}} \quad: \quad$ Shear stress of the fodder beet $(\mathrm{Max} .=\underline{0.281 \mathrm{MPa}})$
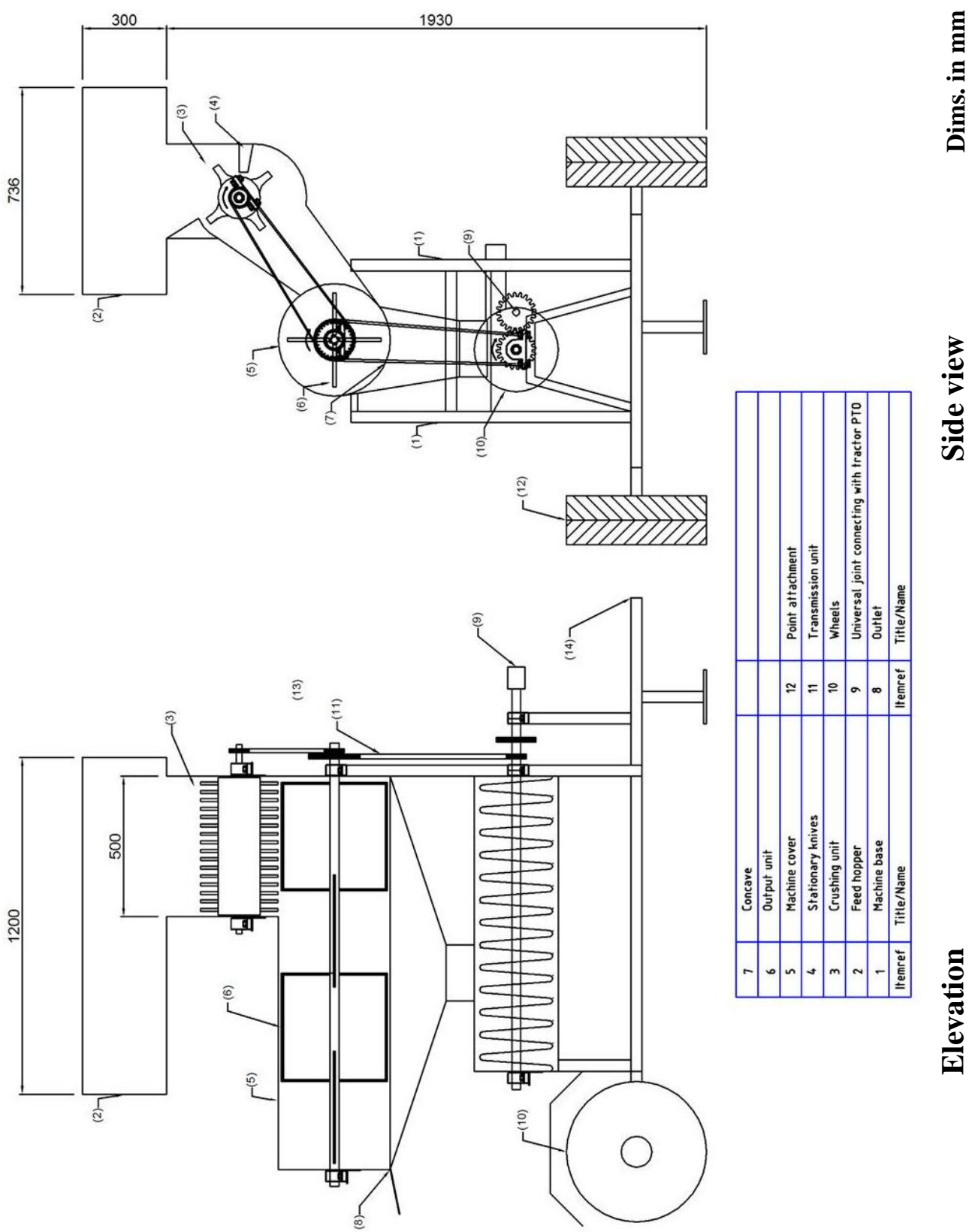

ํㅡㄹ ํㅡㄹ

Fig. (4): Diagrammatic sketch of the modified machine. 


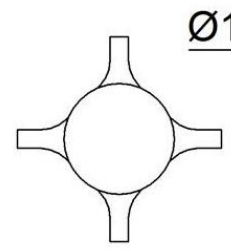

4

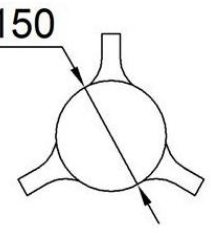

3

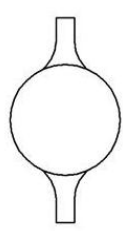

2

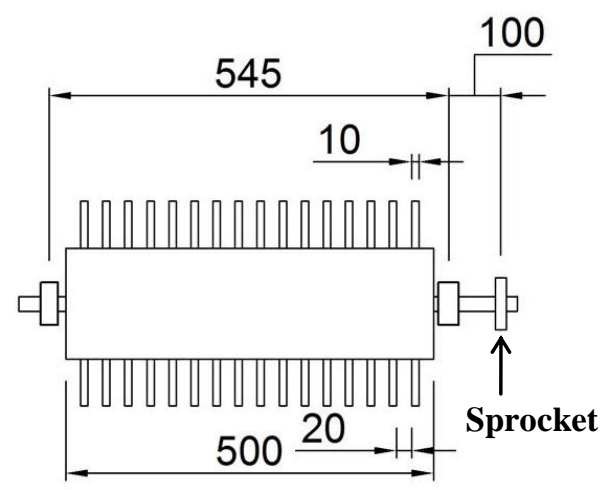

Cutting cylinder

Dims. in mm

Three type of knives

Fig. (5): Cutting cylinder and shaft of cutting unit.

The area of one knife was calculated $\left(2046 \mathrm{~mm}^{2}\right)$. The average force required to shear fodder beet is $574.926 \mathrm{~N}$.

Determination of the power required for cutting the fodder beet: The power required by the chopper to cut the fodder beet may be obtained from the following:

$$
\mathrm{P}_{\mathrm{C}}=\mathrm{F}_{\mathrm{P}} \times \mathrm{N}_{\mathrm{k}} \times \mathrm{V}_{\mathrm{C}}
$$

Where

$\mathrm{P}_{\mathrm{C}}$ : Power required by the cutter, $\mathrm{N}-\mathrm{m} \mathrm{s}^{-1}$.

$\mathrm{N}_{\mathrm{k}}$ : No. of knives that cutting at simultaneously (10 knives).

$\mathrm{V}_{\mathrm{C}}$ : linear velocity of the cutting blade $=7.2 \mathrm{~m} \mathrm{~s}^{-1}$ (at $540 \mathrm{rpm}$ ).

From equation (5), the required power of cutting unit is $41.39 \mathrm{~kW}$.

Design of the rotating shaft: In order to transfer the power from the shaft, the various members (such as pulleys, bearings, and cylinder) are mounted on it. The shaft in this case is exposed to bending moment and torsional forces since it is utilized for torque transmission and bending moment. Hence, the diameter of the shaft was calculated as follows (Eric, 1976):

$$
d^{3}=\frac{16}{\pi S_{s}} \sqrt{\left[K_{b} M_{b}\right]^{2}+\left[K_{t} M_{t}\right]^{2}}
$$

Where

d : $\quad$ Diameter of shaft, $m$.

$\mathrm{M}_{\mathrm{b}} \quad$ : Resultant bending moment, N-m.

$\mathrm{M}_{\mathrm{t}} \quad$ : Torsional moment, N-m. 
$\mathrm{K}_{\mathrm{b}}$ : Combined shock and fatigue factor applied to bending moment.

$\mathrm{K}_{\mathrm{t}}$ : Combined shock and fatigue factor applied to torsional moment.

$\mathrm{S}_{\mathrm{s}} \quad$ : Allowable shear stress of the shaft material, $\mathrm{MN}-\mathrm{m}^{-2}$.

The values of $\mathrm{K}_{\mathrm{b}}$ and $\mathrm{K}_{\mathrm{t}}$ were taken as 1.5 and 1.0 respectively for the gradually applied load on the rotating shaft and the allowable shear stress of the shaft (Ss) as $40 \mathrm{MN}-\mathrm{m}^{-2}$ based on ASME code.

$\mathrm{M}_{\mathrm{b}}$ was calculated by analyzing moments due to both horizontal and vertical loading in bending moment diagrams of the shaft.

$\mathrm{M}_{\mathrm{t}}$ was calculated by the following equation:

$$
M_{t}=\frac{P \times 60}{2 \pi N}
$$

Using $\mathrm{P}=41390 \mathrm{~W}$ and $\mathrm{N}=540 \mathrm{rpm}, \mathrm{M}_{\mathrm{t}}$ was calculated as $732.3 \mathrm{~N}-\mathrm{m}$.

For the cylinder: Weight of cylinder $\left(\mathrm{W}_{\mathrm{C}}\right)$ is $\mathbf{1 0 9 . 5 6} \mathbf{N}$.

The weight of knives $=\mathrm{N}_{\mathrm{k}} \times$ weight of one knife $=101 \mathrm{~N}$, the total weight for cylinder and knives that acting vertical is $210.56 \mathrm{~N}$.

For the chain: Weight of sprocket (Wp), (150 mm - diameter and $40 \mathrm{~mm}$ - thick), equals $54.48 \mathrm{~N}$.

The total load or total tension $\left(\mathrm{F}_{\text {Total }}\right)$ on the driving side of the chain is the sum of the tangential driving force $\left(F_{\mathrm{T}}\right)$, centrifugal tension in the chain $\left(F_{\mathrm{C}}\right)$ and the tension in the chain due to sagging $\left(F_{\mathrm{S}}\right)$. (Khurmi and Gupta, 2005).

$$
\begin{gathered}
\mathrm{F}_{\text {Total }}=\mathrm{F}_{\mathrm{T}}+\mathrm{F}_{\mathrm{C}}+\mathrm{F}_{\mathrm{S}} \\
F_{T}=\frac{P}{v}, F_{\mathrm{C}}=m \cdot v^{2}, F_{\mathrm{S}}=k \cdot m g \cdot x
\end{gathered}
$$

Where

P : Power transmitted, W.

$m \quad$ : $\quad$ Mass of the chain in $\mathrm{kg}$ per meter length $=0.13 \mathrm{~kg} \mathrm{~m}^{-1}$.

$v \quad:$ Speed of chain, $\mathrm{m} \mathrm{s}^{-1}=4.24 \mathrm{~m} \mathrm{~s}^{-1}$.

$\mathrm{g}:$ : Acceleration of gravity, $\mathrm{g}=9.81 \mathrm{~m} \mathrm{~s}^{-2}$.

$\mathrm{x} \quad$ : Centre distance, $\mathrm{m}$.

$k \quad$ : Constant $=2$ to 6 , when the centre line of the chain is inclined to the horizontal at an angle less than $40^{\circ}$.

$\mathrm{F}_{\text {Total }}=9769 \mathrm{~N}$, this load acts at $34^{\circ}$ to the horizontal as shown in Fig. (6) 
Resolving the load $\mathrm{F}_{\text {Total }}$ into vertical and horizontal components (Fig. 6), the vertical component $=\mathrm{F}_{\mathrm{T}} \sin 34^{\circ}=\mathbf{5 4 6 2 . 8} \mathrm{N}$ and the horizontal component of $=\mathrm{F}_{\mathrm{T}} \cos 34^{\circ}=\mathbf{8 0 9 8 . 9} \mathrm{N}$.

Accordingly, the shaft is subjected to vertical and horizontal loads of the values presented in table (1) and figure (6).

Table (1): Vertical and horizontal loads on the shaft.

\begin{tabular}{lcc}
\hline Type of load & At $(\mathbf{A})$ & At $(\mathbf{B})$ \\
\hline Vertical & $210.56 \mathrm{~N}\left(421.12{\left.\mathrm{~N}-\mathrm{m}^{-1}\right)}^{-1}\right.$ & $5517.3 \mathrm{~N}$ \\
Horizontal & - & $8098.9 \mathrm{~N}$ \\
\hline
\end{tabular}

The maximum resultant bending moment $\left(\mathrm{M}_{\mathrm{b}}\right)$ and torsional moment $\left(\mathrm{M}_{\mathrm{t}}\right)$ were calculated and were found 732.3 and $490 \mathrm{~N}-\mathrm{m}$ respectively. By applying the calculated values of the different items in equation (6), shaft diameter should be equal or more than $51 \mathrm{~mm}$.

\subsection{Transmission unit}

Figure (7) shows the modified transmission unit for developed machine. It used the sprocket and chain to transform the motion starting from PTO of tractor to cutting shaft. According to Khurmi and Gupta (2005) the relation between the speed and the number of teeth ad following:

$$
\mathrm{N}_{1} \mathrm{~T}_{1}=\mathrm{N}_{2} \mathrm{~T}_{2}
$$

Where

$\mathrm{N}_{1}, \mathrm{~N}_{2} \quad$ : Speed of driving and driven shaft respectively, rpm.

$\mathrm{T}_{1}, \mathrm{~T}_{2} \quad$ : Number of teeth for driving and driven shaft respectively, teeth.

The machine will operate at four speeds at the cutting shaft: 325 (4.7), 405 (5.9), 460 (6.7) and 540 (7.2) rpm ( $\left.\mathrm{m} \mathrm{s}^{-1}\right)$. The speed of PTO shaft is $540 \mathrm{rpm}$. So, Substituting the required speeds at the cutting unit, the teeth number of sprocket at The shaft of modified Cutting unit $\left(\mathrm{T}_{6}\right)$ were calculated according to the required speed.

\section{Treatments}

The development machine was evaluated at four different levels of moisture content of fodder beet, three numbers of arrange knives rows and three levels of rotor speed (table 2). 


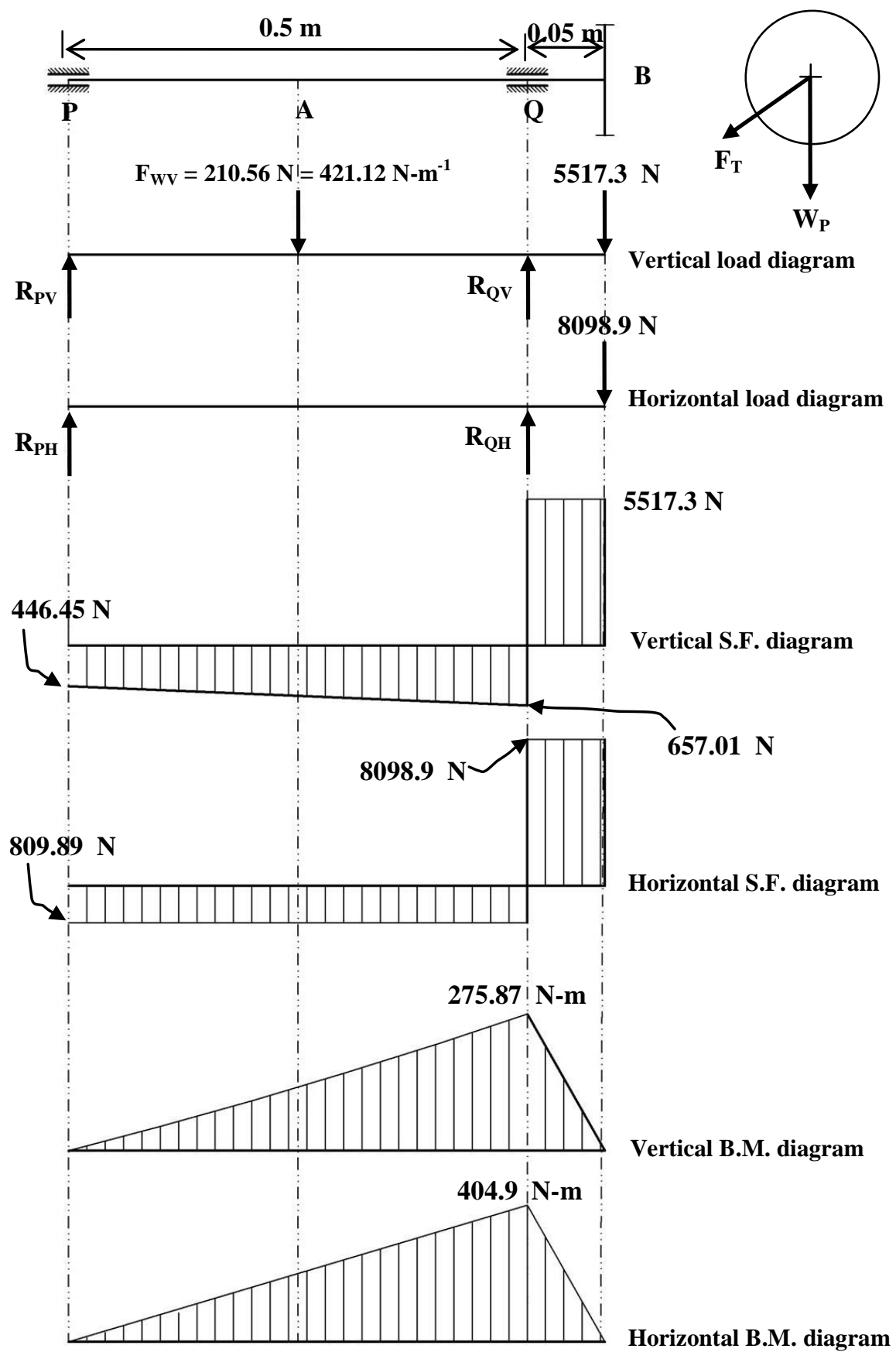

Fig. (6): The shearing and bending moment diagrams of the shaft. 
Table (2): Experimental plan of the evaluation machine.

\begin{tabular}{llll}
\hline \multicolumn{1}{c}{ Variables } & Levels \\
\hline Moisture content, $\mathrm{M}_{\mathrm{C}}(\%$ w.b) & $86.2,81.3,76.85$ & & \\
Number of knives rows, $\mathrm{N}_{\mathrm{K}}$ & $2,3,4$ & & \\
Rotary speed of cutting shaft, $\mathrm{R}_{\mathrm{S}}, \mathrm{rpm}$ & $325 \quad(4.7), 405 \quad(5.9), \quad 460$ \\
$\left(\mathrm{~m} \mathrm{~s}^{-1}\right)$ & $(6.7), 540(7.2)$ & \\
\hline
\end{tabular}

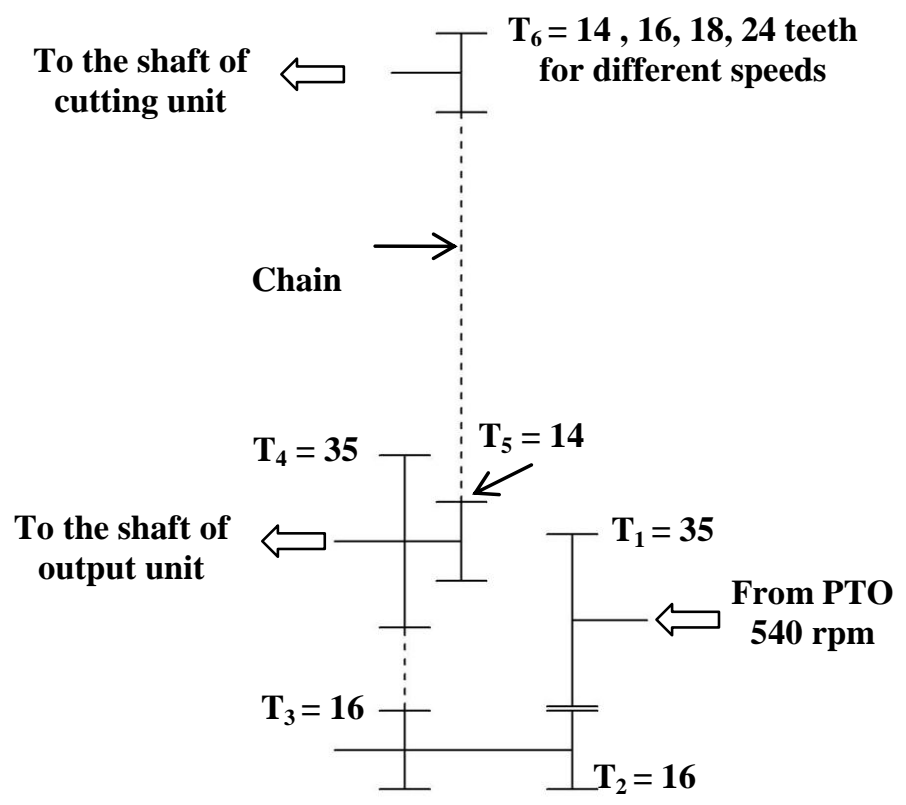

Fig. (7): Transmission system of modified machine.

\section{Evaluation criteria}

Evaluation of the machine was performed taking into consideration the following indicators:

\subsection{Fineness degree modulus (FDM)}

Three $100 \mathrm{~g}$ milled samples from the output fodder beet shall be shaken using a laboratory sieve shaker with standard screen sieves for a period of 10 min. After shaking, to determine the particle size distribution of the output product was determined (ASAE 1999a), based on the total weight of samples and the mass of each product categories were weighed. The cutting fodder beet samples were classified into four main categories 
according to Henderson and Hansen (1968). The first one is $(<2 \mathrm{~cm})$, the second is $(2-4 \mathrm{~cm})$, the third is $(4-6 \mathrm{~cm})$ and the fourth is $(>6 \mathrm{~cm})$.

\subsection{Machine capacity $\left(\mathbf{P}_{\mathrm{m}}\right)$}

The machine capacity was calculated as follows:

$$
\mathrm{P}_{\mathrm{m}}=\frac{\mathrm{W}}{\mathrm{T}}
$$

Where

$\mathrm{P}_{\mathrm{m}} \quad$ : The machine capacity, $\mathrm{kg} \mathrm{h}^{-1}$.

W : The mass of sample, $\mathrm{kg}$.

$\mathrm{T}$ : Cutting time, hour.

\subsection{Required power (RP) and consumed energy (CE)}

The fuel consumption was measured using special device consists of 3 liter graduated cylinder was connected to fuel pump. The reduction of fuel in tube after executing each treatment was recorded.

Power consumption was calculated according the principles and assumption of Hunt (1983), ad using the following equation (Embaby 1985):

$$
R P=\frac{F C \times \rho_{f} \times L . C . V \times 427 \times \eta_{m} \times \eta_{t h}}{3600 \times 75 \times 1.36}
$$

Where

RP : Required power, $\mathrm{kW}$.

FC : Fuel consumption, $1 \mathrm{~h}^{-1}$.

$\rho_{\mathrm{f}} \quad: \quad$ Density of the fuel, $850 \mathrm{~kg} \mathrm{~m}^{-3}$.

L.C.V : Lower calorific value of fuel, $10000 \mathrm{kcal} \mathrm{kg}^{-1}$.

427 : Thermo - mechanical equivalent, kg. $\mathrm{m} \mathrm{kcal}^{-1}$.

$\eta \mathrm{m} \quad: \quad$ Mechanical efficiency of engine, $80 \%$ and

$\eta_{\text {th }} \quad$ : Thermal efficiency of the engine, (considered to be about $35 \%$ for diesel engine).

The consumed energy (CE) is specific power per unit capacity; it was calculated by using the following equation:

Consumed energy $=\left(\mathrm{P} / \mathrm{P}_{\mathrm{m}}\right), \quad \mathrm{kW} \cdot \mathrm{h} \mathrm{ton}^{-1}$

\subsection{Costs}

Machine cost was determined using the fixed costs and variable costs according to Srivastava et al. (2006). The operational cost was determined using the following equation: 


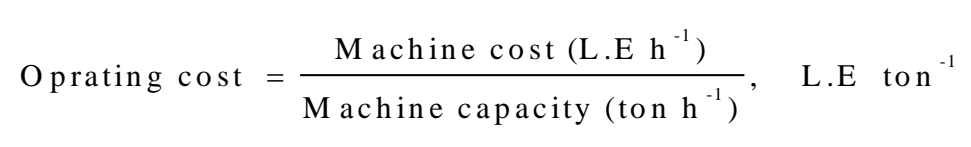

\section{RESULTS AND DISCUSSION}

\section{Fodder beet tuber properties}

The measured physical and mechanical properties of the fodder beet are presented in table (1).

Table (1): Physical and mechanical properties of fodder beet tuber.

\begin{tabular}{lcccc}
\hline \multirow{2}{*}{\multicolumn{1}{c}{ property }} & \multicolumn{4}{c}{ Value } \\
\cline { 2 - 5 } & Max. & Min. & Mean & Stand. Dev. \\
\hline Length $(\mathbf{c m})$ & 28.6 & 25.5 & 27.3 & 1.4 \\
Diameter $(\mathbf{c m})$ & 24.5 & 22.8 & 23.7 & 0.8 \\
Mass $(\mathbf{g})$ & 4234 & 3518 & 3870 & 332.7 \\
Volume $\left(\mathbf{c m}^{\mathbf{3}}\right)$ & 3636 & 2858 & 3465 & 361.5 \\
Static coefficient of friction & 0.357 & 0.533 & 0.433 & 0.14 \\
Shearing stress $(\mathbf{M P a})$ & 0.235 & 0.341 & 0.281 & 0.13 \\
Shearing energy $\left(\mathbf{m J ~} \mathbf{~ m m}^{-\mathbf{2}}\right)$ & 3.895 & 5.797 & 4.91 & 1.51 \\
\hline
\end{tabular}

\section{Chopping sizes}

Figures (8), (9) and (10) illustrate the effect of rotor speeds, number of knives rows and beet moisture contents on chopping sizes. The chopping sizes decreased by increasing the rotor speed. It is clear that, the highest values of beet sizes $<2 \mathrm{~cm}$ were $71 \%$ take found at rotor speed of 540 rpm, number of knives rows 4 rows and beet moisture content of $81.3 \%$. Hence, the highest values of beet sizes were $30 \%$ for the range of $>2-4$ $\mathrm{cm}$ at rotor speed of $540 \mathrm{rpm}$, of knives rows 4 rows and beet moisture content of $86.2 \%$.

Meanwhile, the increase of rotor speeds decreases the beet sizes of 4-6 $\mathrm{cm}$. Whereas, the minimum values were $0 \%$ which occurred place at rotor speed of $540 \mathrm{rpm}$, of knives rows 4 rows and beet moisture content of $86.2 \%$. The obtained results showed that, the highest values of beet sizes $>6 \mathrm{~cm}$ were $16 \%$ at rotor speed of $325 \mathrm{rpm}$, of knives rows 2 rows and beet moisture content of $76.85 \%$. 
According to chopping size, it can be stated that the best treatment was moisture content of $86.2 \%$, rotor speed of $540 \mathrm{rpm}$, and knives rows 4 rows.

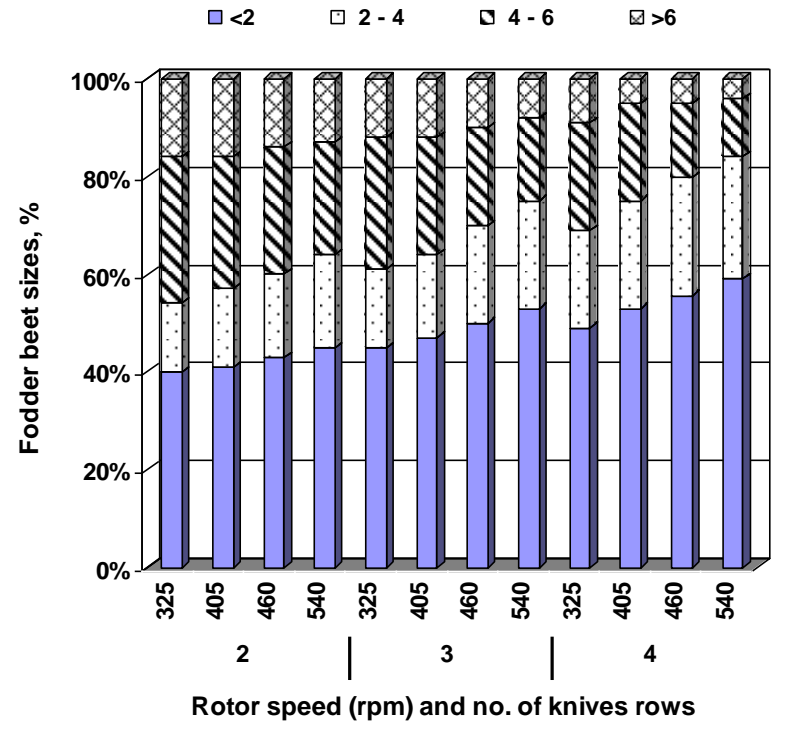

Fig. (8): The effect of number of knives rows and rotor speed on the beet size at $76.85 \%$ moisture content.

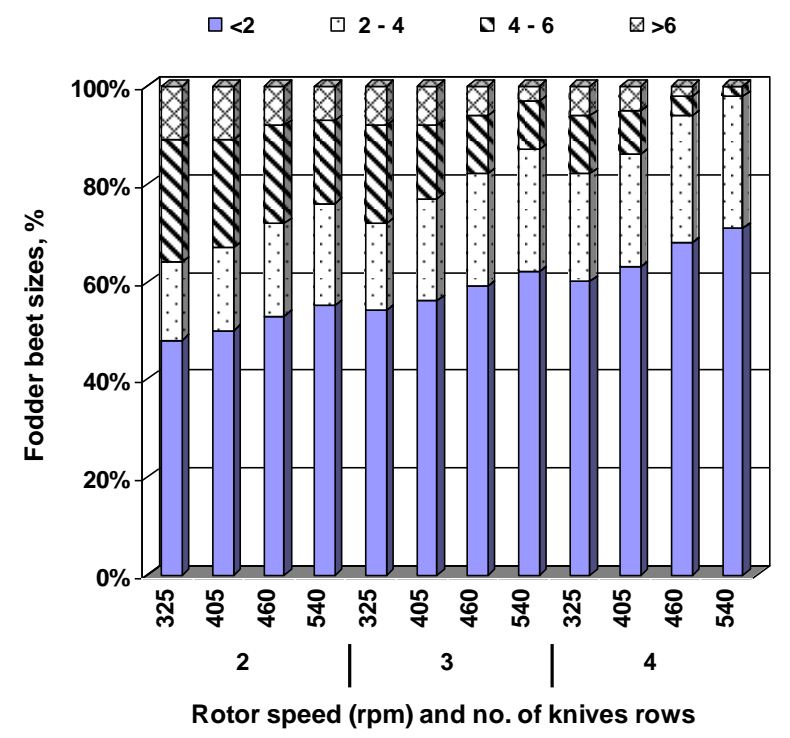

Fig. (9): The effect of number of knives rows and rotor speed on the beet size at $81.3 \%$ moisture content. 


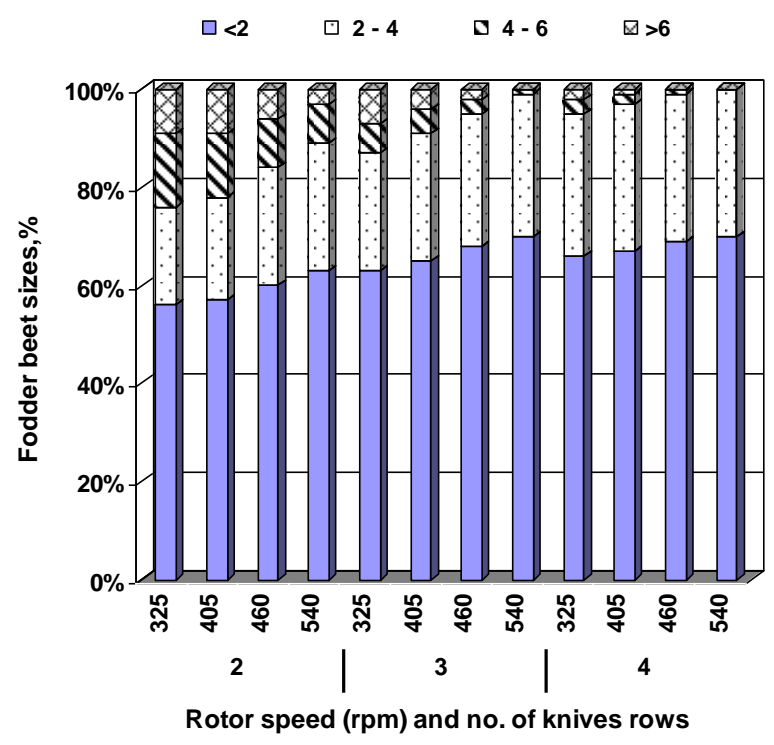

Fig. (10): The effect of number of knives rows and rotor speed on the beet size at $86.2 \%$ moisture content.

\section{Machine productivity}

The figure (11) shows the productivity of the developed machine is affected by beet moisture content, rotor speeds, and number of knives rows. It is clear that the increment in beet moisture content from 76.85 to $86.2 \%$ tend to increase the machine productivity. The maximum value of machine productivity was obtained with the rotor speeds of $540 \mathrm{rpm}$ for all beet moisture content and number of knives rows. The data also revealed that the machine productivity increased when the number of knives rows increased for all the beet moisture contents and rotor speeds. Generally, it is clear that the beet moister content of $86.2 \%$, rotor speed of $540 \mathrm{rpm}$ and number knives rows of 4 rows gave the maximum machine productivity of 10.25 ton $\mathrm{h}^{-1}$, but the minimum machine productivity of 7.15 ton $\mathrm{h}^{-1}$ was recorded with the beet moisture content of $76.85 \%$, rotor speed of $325 \mathrm{rpm}$ and number knives rows of 2 rows.

According to the machine productivity, it can be stated that the best size treatment was moisture content of $86.2 \%$, rotor speed of $540 \mathrm{rpm}$, and knives rows 4 rows.

\section{Consumed Energy}

Fig. (12) shows the effect of beet moisture content, rotor speed and number of knives rows on the consumed energy. It is clear that, the 
consumed energy increased by decreasing the beet moisture content for all rotor speed and number of knives rows. The minimum value of consumed energy, $1.02 \mathrm{~kW} . \mathrm{h}$ ton $^{-1}$ was achieved at $86.2 \%$ moisture content, $325 \mathrm{rpm}$ rotor speed and 4 rows cutting knives. These results may be due to increasing rotor speed and number of knives rows led to increase consumed energy in unit time through the material of beet bulb.

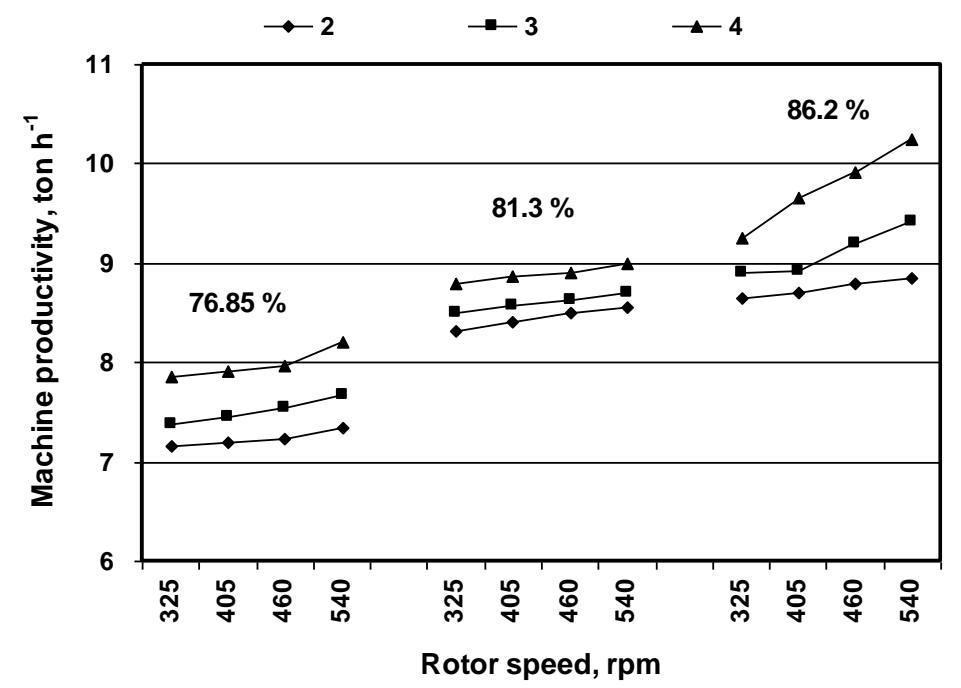

Fig. (11): The effect of moisture content, number of knives rows and rotor speed on the machine productivity.

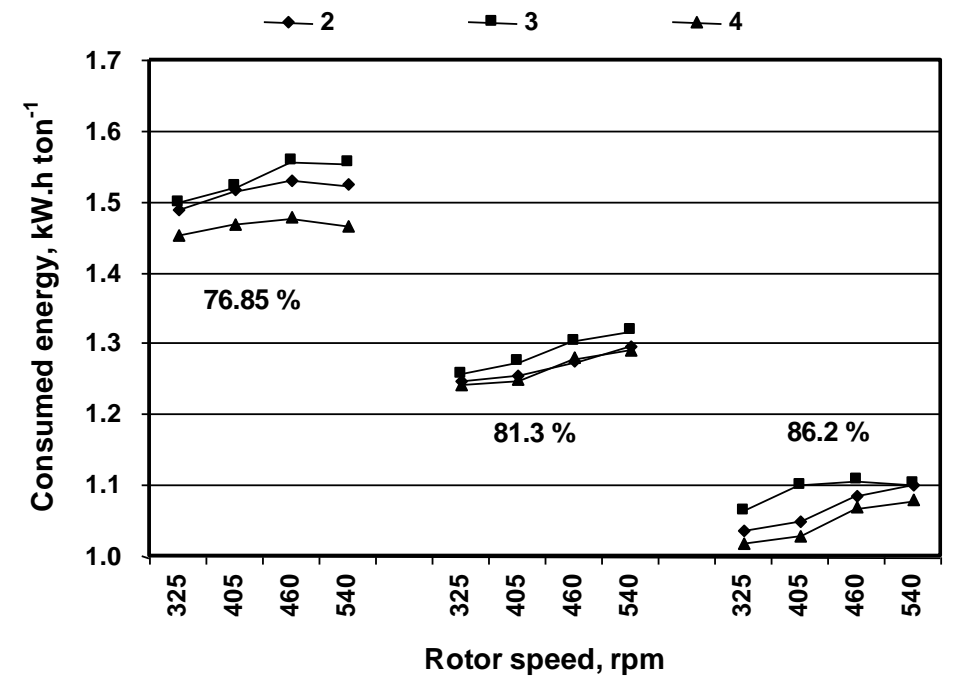

Fig. (12): The effect of moisture content, number of knives rows and rotor speed on the consumed energy. 


\section{Chopping cost}

The Fig. (13) shows the effect of beet moisture content, rotor speed and number of knives rows on the chopping cost of beet. It was noticed that the increase in beet moisture content from 76.85 to $86.2 \%$ tend to decrease the chopping cost of beet. The minimum chopping cost of beet was obtained with the beet moisture content of $86.2 \%$ for all rotor speed and number of knives rows. The data also showed that the chopping cost of beet decreased by increasing the number of knives rows from 2 to 4 rows for all the beet moisture contents and rotor speeds. The number of knives rows of 4 rows gave the maximum average value of chopping cost of 20.49 L.E ton $^{-1}$ at moisture content of $86.2 \%$ and rotor speed of 540 rpm. Generally, it is clear that the moister content of $86.2 \%$, number of knives rows of 4 rows and rotor speed of $540 \mathrm{rpm}$ gave the least chopping cost of 20.49 L.E ton ${ }^{-1}$.

The results recommended operating the machine at rotor speed of 540 rpm, number of knives rows of 4 row and beet moisture contents of 86.2 $\%$.

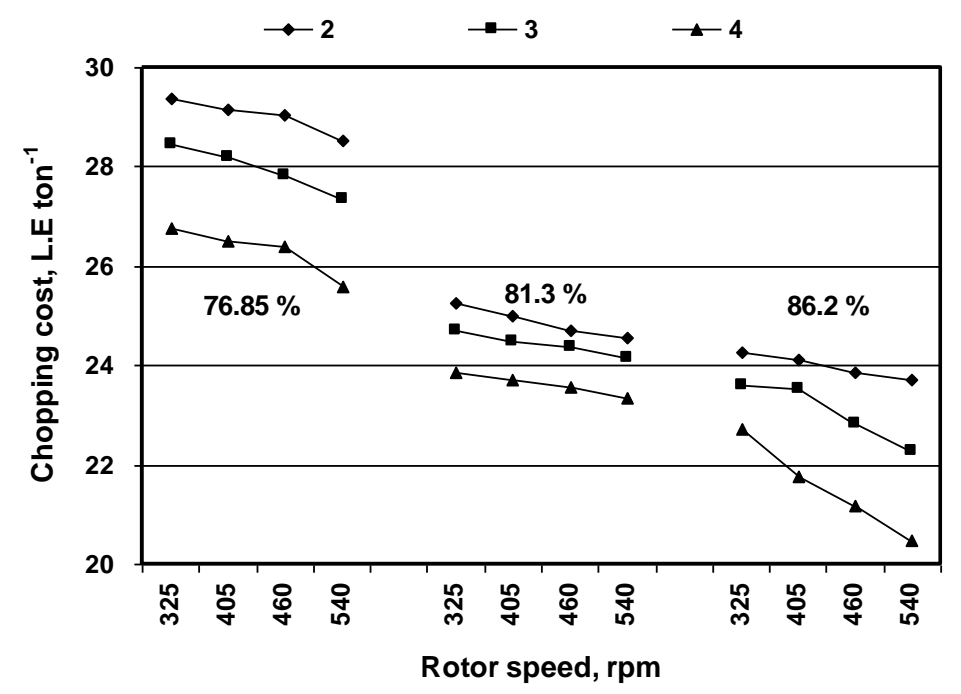

Fig. (13): The effect of moisture content, number of knives rows and rotor speed on the chopping cost. 


\section{CONCLUSION}

The obtained results can be summarized as follows:

1. The developed machine for chopping fodder beet provided the optimum performance in chopping sizes where, the machine productivity reached 10.25 ton $\mathrm{h}^{-1}$, consumed energy $1.04 \mathrm{~kW} . \mathrm{h}$ ton $^{-1}$ and chopping cost of 20.49 L.E ton ${ }^{-1}$.

2. The results showed that increasing both beet moisture content and rotor speed tend to increase the machine productivity, chopping sizes $(<2$ and 2- $4 \mathrm{~cm}$ ) for all the number of knives rows.

3. The results indicated that the increment in rotor speed tend to increase machine productivity and consumed energy while chopping cost decreased.

4. The data demonstrated that the beet moisture content of $86.2 \%$, rotor speed of $540 \mathrm{rpm}$ and number of knives rows of 4 rows recorded the maximum values of chopping sizes $<2$ and $2-4 \mathrm{~cm}$.

5. It is recommended to operate the developed machine at beet moisture content of $86.2 \%$, rotor speed of $540 \mathrm{rpm}$ and number of knives rows of 4 rows to obtain the optimum performance.

\section{REFERENCES}

Abou-Elela, A. M. and R. A. Gadallah. 2012. Effect of transplanted seedling age of intercropped fodder beet with faba bean and nitrogen fertilizer levels on yield and its component of fodder beet and faba bean. Zagazig J. Agric. Res., Vol. 39 No. (6): 1057-1067.

Aky ld z, A. R. 1983. Yemler Bilgisi ve Teknolojisi. Ankara Üniv. Zir.Fak. No: 868. Ankara.

ASABE Standards. S358.2 DEC98. 1999 a. Measurement - forages. St. Joseph, MI: ASABE.

ASAE Standards. S459 MAR98. 1999 b. Shear and three-point bending test of animal bone. St. Joseph, MI: ASABE.

Chen Y., J. L. Gratton, and J. Liu. 2004. Power requirements of hemp cutting and conditioning. Biosys. Eng., 87(4): 417-424. 
DAF, Department of Agriculture and Food. 1988. Root, fodder crop, pulse and oil seed varieties. Irish. recommended list Government Stationary Office, Dublin, 17p.

Embaby, A. T. 1985. A comparison of different mechanization systems for Cereal crop production. M.Sc. Thesis. Ag. Eng. Cairo Univ.

Eric, O. 1976. Machinery's Hand Book. 20th ed. New York, Industrial Press .

FAOSTAT. 2010. FAO Statistical Yearbook. Agricultural production.

Gabra, M. A., A. M. Khinizy and S. I. Hafez. 1993. Feeding qualities and some mineral balances of fresh and stored fodder beet (Beta Vulgaris L.) leaves and roots in metabolism trials with sheep. J. Agric. Sci. Mansoura Univ., 18: 2897- 2906.

Hashish, A. E., M. A. Hassan and A. F. El-Mottalb. 1994. Some factors affecting performance of chopping and crushing for field raw materials. Misr J. Agric. Eng., 11 (3): 669 - 682.

Henderson, S. M., and P. L. Hansen. 1968. Hammer mill and Burr mill performance analyzed. Trans. of the ASAE., 11(3):399-402.

Hunt, D. 1983. Farm power and machinery management 8 th Ed.,Iowa state Univ., Press Ames, U.S.A.

Ibrahim M. M. 2008. Determination of dynamic coefficient of friction for some materials for feed pellet under different values of pressure and temperature. Misr J. Ag. Eng., 25(4):1389-1409.

Ibrahim, Y. M. 2005. Ranges and forage In Arabic. Dar Azza for Publication, Khartoum, Sudan, 300p.

Kassab, O. M., S. A. Orabi, and A. A. Abo Ellil. 2012. Physiological response to potassium application in fodder beet plant grown under water stress. Australian Journal of Basic and Applied Sciences, 6 (13): 566-574, 2012 
Kholief, R. M. 2001. Energy requirements of chopping operation for fodder beet. Misr J. Agric. Eng., 18 (3): 612- 628.

Khurmi, R. S. and J. K. Gupta. 2005. Theory of Machines. New Delhi: Eurasia Publishing house.

Mohamed, A. 1998. Design and development of a sugar beet topper. Ph. D. thesis Agric. Mech. Dept. Faculty of Agriculture. Ain Shams Univ.

Mohsenin, N. N. 1986. Physical properties of plant and animal materials. 2nd ed. Gordon and Breach Sc. Publishers.

Persson, S. 1987. Mechanics of Cutting Plant Material. ASAE Publications, Michigan.

Shalaby, A. S., Rammah, A.M., Abdul- Aziz, G. M. and Beshay, M. G. 1989. Fodder beet, a new forage in Egypt. 1. Productivity and the chemical analysis of some Fodder beet Beta vulgaris L. cultivars sown at different locations in Egypt. In proceedings of the third Egyptian British Conference on Animals, fish and poultry production. Alexandria, Egypt, 13: 133-143.

Srivastava, A. K., C. E. Goering, R. P. Rohrbach and D. R. Buckmaster. 2006. Engineering principles of agricultural machines. St. Joseph, Mich.: ASAE.

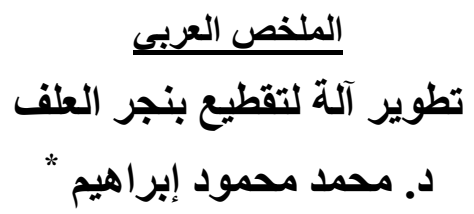

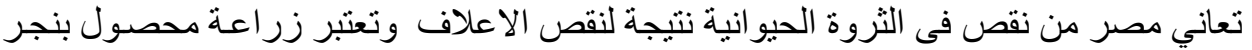
العلف أحد الحلول الفعالـة للتغلب على مشكلة نقص العلف الصيفى، وحيث أن إنى إنتاجيـة الفدان

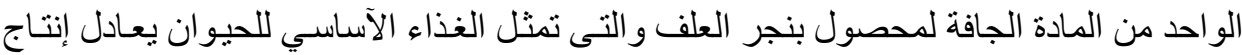

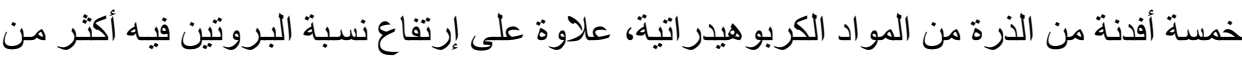

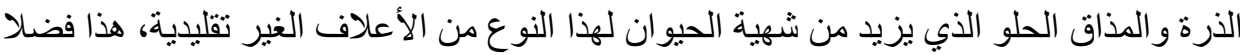
عن إنتاجه فى شهر يونيو حيث قمة الإحتياج إلى المو اد النشوية اللازمة للأعلاف لألاف.

" استاذ الهندسة الزراعية المساعد ـ كلية الزراعة ـ جامعة القاهرة. 


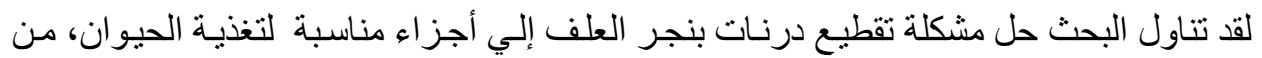

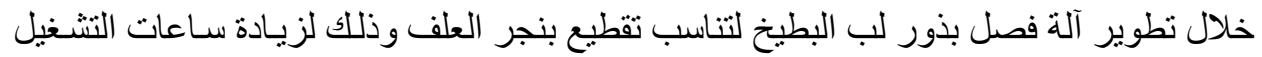

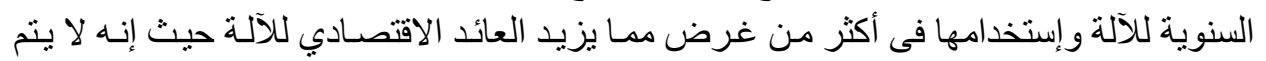
إستخدام الآلة أكثر من شهر فى العام. وقد تم التطوير من خلال مرحلتين للتعديل:

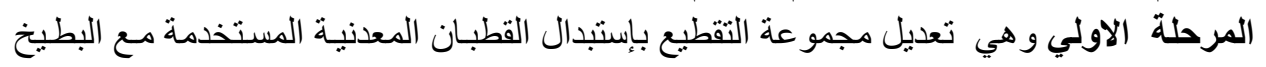

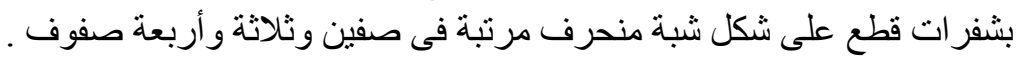

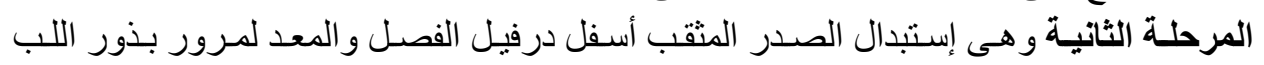

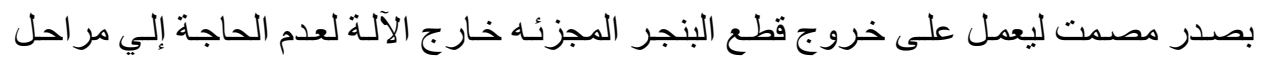
التنظيف أثناء تقطيع درنات بنجر العلف.

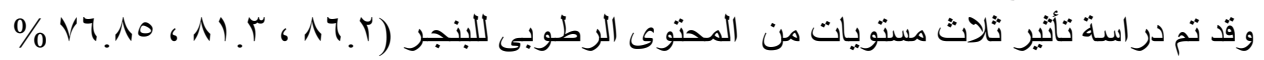

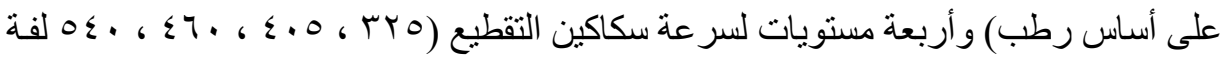

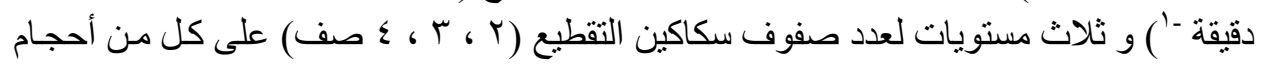
التقطيع و إنتاجية الآلة والطاقة المستهلكة وتكاليف عملية تقطيع بنجر العلف.

\section{يمكن تلخيص النتائج المتحصل عليها فيما يلي:}

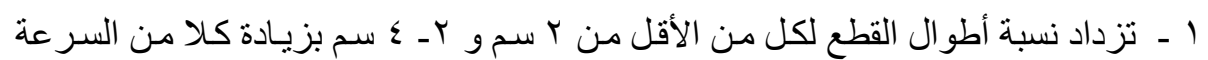

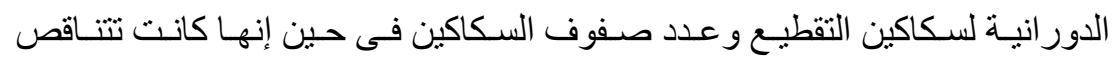
بتناقص المحتوي الرطوبي للبنجر .

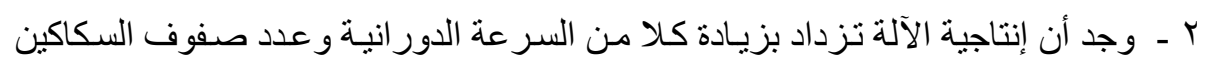

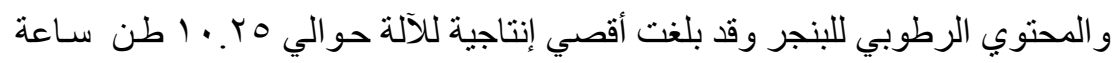

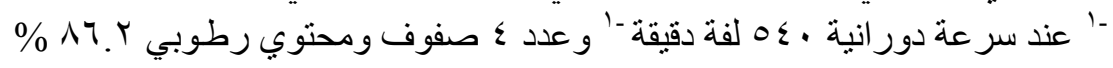

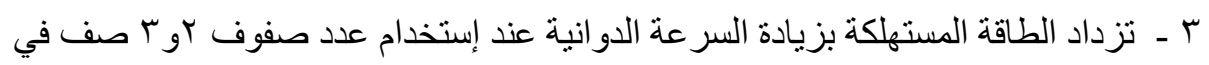

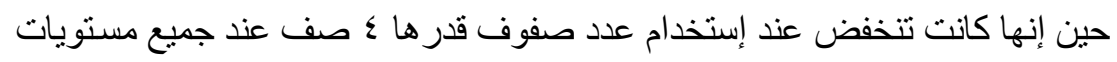
المحتوي الرطوبي المستخدمة فى الدراسة.

ـ ـ تناقصت تكاليف عملية التقطيع بزيادة كلا من السر عة الدور انية لسكاكين التقيع و عدد

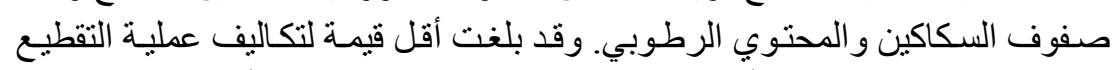

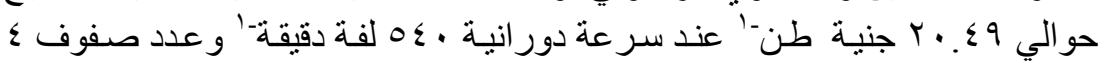

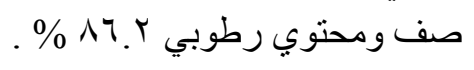

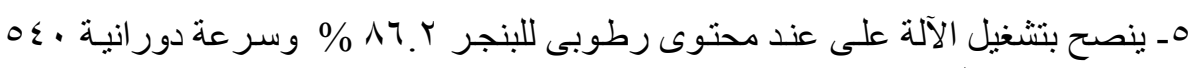
لفة دقيقة -' و عدد ع صفوف من الالة على السكاكين. 